\title{
Health surveillance in day-care centers: analysis of nutritional status in children under two years old
}

\author{
Vigilância em saúde em creches: análise do estado nutricional em menores de dois anos
}

Isolda Maria Barros Torquato ${ }^{1}$, Hyana Pereira Dias ${ }^{2}$, Neusa Collet ${ }^{1}$, Maria Amélia de Souza ${ }^{3}$, Meryeli Santos de Araújo Dantas ${ }^{4}$, Altamira Pereira da Silva Reichert ${ }^{1}$

Objective: to evaluate the nutritional status of assisted children in municipal public daycare centers. Methods: This is a cross-sectional study, carried out with 137 children between zero and 24 months old., The anthropometric measures recommended by the Ministry of Health were used for data collection, including height, weight, and body mass index, and, descriptive and inferential statistics were used for analysis. Results: more than half of the children were eutrophic (70.7\%), but $24.1 \%$ were overweight, most of them were male. Pictures of thinness (5.2\%) were also identified in children between six and 24 months old. Conclusion: the results of the nutritional evaluation indicate a trend towards reduction of malnutrition rates and elevation of overweight in childhood, which reinforces the importance of anthropometric evaluation in the identification of nutritional alterations in children using daycare centers.

Descriptors: Nutritional Surveillance; Nutritional Status; Child Health.

Objetivo: avaliar o estado nutricional de crianças assistidas em creches públicas municipais. Métodos: pesquisa transversal realizada com 137 crianças entre zero e 24 meses. Para coleta de dados, utilizaram-se as medidas antropométricas preconizadas pelo Ministério da Saúde, incluindo estatura, peso e índice de massa corporal, e, para análise, as estatísticas descritiva e inferencial. Resultados: mais da metade das crianças apresentaram-se eutróficas $(70,7 \%)$, porém $24,1 \%$ delas apresentaram sobrepeso, sendo a maioria do sexo masculino. Quadros de magreza $(5,2 \%)$ também foram identificados em crianças entre os seis e 24 meses. Conclusão: os resultados da avaliação nutricional sinalizam para a tendência de redução das taxas de desnutrição e elevação do sobrepeso na infância, o que reforça a importância da avaliação antropométrica na identificação de alterações nutricionais em crianças usuárias de creches.

Descritores: Vigilância Nutricional; Estado Nutricional; Saúde da Criança.

\footnotetext{
${ }^{1}$ Universidade Federal da Paraíba. João Pessoa, PB, Brazil.

${ }^{2}$ Universidade Federal de Campina Grande. Cuité, PB, Brazil.

${ }^{3}$ Universidade Federal de Pernambuco. Recife, PE, Brazil.

${ }^{4}$ Centro Universitário de João Pessoa. João Pessoa, PB, Brazil. 


\section{Introduction}

The growth, dynamic and continuous process expressed by the increase in body size is considered one of the most important indicators of child health. This is because stature delay is the most effective anthropometric characteristic for the determination of nutritional deviations in this people $\mathrm{e}^{(1)}$.

Approximately 190 million children under five years old are estimated to be chronically malnourished worldwide, and half of the deaths among children in this age group in underdeveloped countries may be a primary or associated cause ${ }^{(2)}$.

In Brazil, the situation does not differ from the world reality, although an improvement of the indicators related to the nutritional profile is observed. Data from the National Demographic and Health Survey revealed prevalence of malnutrition due to short stature in children under five years old, and the Northeast is among the regions with the worst rates found ${ }^{(3)}$. Besides to malnutrition, another problem related to nutritional disorders refers to the growing number of overweight and obese children in the pre-school and school-age groups ${ }^{(4)}$.

In view of the importance of the evaluation of growth and development for the risks of infant morbidity and mortality, the World Health Organization and the Brazilian Society of Pediatrics consider them central axes for child care, which are treated as mandatory components in the Primary Health Care of the child(5).

Growth surveillance is aimed at the early identification of infant nutritional deviations to provide immediate intervention so the growth process occurs in a healthy way ${ }^{(6)}$. It is a simple, non-invasive, inexpensive method that allows the rapid and effective identification of the repercussions of the child's nutritional conditions.

In this sense, the Ministry of Health guides the use of anthropometric indexes, such as weight, height (length and height), head circumference and body mass index for the age as important indicators of nu- tritional status, especially during the pre-school age $\mathrm{e}^{(6)}$. Thus, for these measures to become growth rates, they must be closely linked.

The most used indices for assessing child growth are weight/age, weight/height, height/age, and body mass index for the age. The body mass index for the age expresses the linear growth of children and corresponds to the data that best represents the cumulative effect of adverse conditions on their growth, being considered the most sensitive index to measure the quality of life of the child population ${ }^{(7)}$.

The growth process is influenced by a network of biological, socioeconomic, demographic, cultural and environmental variables which may delay or accelerate its natural course ${ }^{(1)}$. Thus, it is critical that the analysis of linear growth occurs judiciously during the first 36 months of life of the child since the recovery of shortness of stature is restricted after two years old. Also, knowledge of the nutritional status of children in different regions of the country subsidizes the institution of public programs and policies, as well as a better redistribution of resources by managers for the fight against nutritional disorders ${ }^{(8)}$.

The justification for this research is based on the principle that the state of physical growth reflects the living conditions of a population and it is considered an important indicator of the child's health ${ }^{(6)}$. Follow-up is considered a priority in children up to 10 years old. Moreover, in the Brazilian Northeast, physical growth is considered one of the worst health indicators among children under 24 months, which raises the importance of conducting research in this region $^{(3)}$.

This study aimed to evaluate the nutritional status of children attending public daycare centers.

\section{Methods}

This is a cross-sectional research, developed in six public daycare centers in the rural and urban area of the city of Cuité, PB, Brazil. These daycare centers were attended by a population of 392 children betwe- 
en zero and four years old, considered low income. Children who were between zero and 24 months old and who regularly attended daycare centers in that city were selected. The justification for the choice of children in this age group is based on the recommendation of the Ministry of Health, which recommends to identify possible deviations of the nutritional status of the child as an anthropometric assessment priority, aiming at the establishment of specialized treatment in a timely manner. Children who presented physical, visual, auditory, mental or communication disorders were excluded because they are factors that interfere with the nutritional status of the child. Thus, the sample consisted of 137 children in the desired age group, since none of them presented exclusion factors.

The legal caregivers of the children were invited to participate in a meeting with the researcher, to present the objectives, the nutritional assessment method of the children, the risks, the benefits and the relevance of the research. Data collection took place between March and July 2017, in the daycare facilities.

A structured instrument was divided into two parts, the first one related to the maternal characterization (sociodemographic aspects) and the children (age, birth weight, gestational age, vaccination schedule, childcare, age of insertion and length of stay in daycare), and the second part related to the evaluation of children regarding anthropometric measures. For the evaluation of the nutritional diagnosis, the anthropometric measurements, including weight and length/height were used, based on the patterns of growth curves established by the World Health Organization $^{(9)}$.

The cut-off point parameters were represented by the $\mathrm{Z}$ score as the median, and the children's weight and height/height were classified according to age in high ( $>+2 \mathrm{Z}$ ), suitable ( $\geq 2$ and $\leq+2 \mathrm{Z}$ ), low $(\geq-3$ and $<-2$ $\mathrm{Z}$ ) and very low ( $<-3 \mathrm{Z})$; ( $\leq+3$ and $\geq+2 \mathrm{Z}$ ), overweight $(\leq+2$ and $>+1 \mathrm{Z})$, suitable $(\leq+3 \mathrm{Z})$, overweight +1 and $>-2 \mathrm{Z}$ ), thinness ( $<-2$ and $\geq-3 \mathrm{Z}$ ) and sharp thinness $(<-3 \mathrm{Z})^{(9)}$.

Measurements were performed according to standardized technical standards, corresponding to the algorithms recommended by the Ministry of Health. The children were measured by a horizontal wooden anthropometer (Alturexata ${ }^{\circledR}$ ) with a $130 \mathrm{~cm}$ amplitude and $0.1 \mathrm{~cm}$ subdivisions. For weight determination, a pediatric scale or the electronic "baby-type" scale was used, in which the child was positioned naked. Statistical Package for Social Sciences software was used to analyze the data.

A descriptive analysis of maternal and child sociodemographic characteristics was carried out. Subsequently, the inferential analysis was performed, using the chi-square test and the Fisher's exact test, to verify the association of the variables, and also the prevalence ratios were calculated. For this, significance levels of $5 \%(\mathrm{p}<0.05)$ were adopted.

The study complied with the formal requirements contained in the national and international regulatory standards for research involving human beings.

\section{Results}

There was a predominance of mothers aged between 20 and 29 years old (65.0\%), followed by mothers aged between 30 and 40 years old $(23.4 \%)$. The interviewees had a low level of education, considering that most of them had Elementary School (79.6\%) and High School (15.3\%) and 2.2\% were not literate. They had a stable marital union (67.9\%). The paid work activities were limited to a few women (28.5\%), since most of them were dedicated to household chores, reducing the concentration of family income, which was below a minimum wage $(71.5 \%)$. Women who worked for paid work did it sporadically and received as day laborers. Also, $61.3 \%$ of the households did not have basic sanitation, and the number of people living in the household, including all types of kinship, was 4 to 5 members (62.0\%).

As for children enrolled in day-care centers, most were male (55.5\%); 66.4\% were between 13 and 24 months old, followed by $30.7 \%$ between six 
and 12 months old and $2.9 \%$ under six months old. It was observed that $81.0 \%$ were born at term, $11.0 \%$ were premature and $8.0 \%$, post-term. Most children (81.8\%) were born weighing $\geq 2,500 \mathrm{~g}$, but $18.2 \%$ of them presented low birth weight. Also, $88.8 \%$ of the children had outdated vaccination records and $22.6 \%$ did not carry out childcare on a regular basis. Most of the children were enrolled in the nursery before 12 months old (64.2\%), with full-time attendance (83.2\%), 66.4\% of them living in the urban area.

Table 1 shows the anthropometric measures of children using municipal day care centers, considering the classification parameters established by the World Health Organization in force, with a Z score indicating how much the standard deviation of the data obtained was far from its reference median.

Table 1 - Anthropometric measures of children in municipal daycare

\begin{tabular}{|c|c|c|c|c|c|c|}
\hline \multirow[t]{2}{*}{ Variables } & \multicolumn{2}{|c|}{$\begin{array}{c}<6 \text { months } \\
n(\%)\end{array}$} & \multicolumn{2}{|c|}{$\begin{array}{c}\text { 6-12 months } \\
n(\%)\end{array}$} & \multicolumn{2}{|c|}{$\begin{array}{c}\text { 13-24 months } \\
\text { n (\%) }\end{array}$} \\
\hline & Female & Male & Female & Male & Female & Male \\
\hline \multicolumn{7}{|l|}{ Weight/age } \\
\hline Suitable & $1(0.7)$ & $3(2.2)$ & $14(10.2)$ & $16(11.7)$ & $34(24.8)$ & $43(31.4)$ \\
\hline Low & - & - & $4(2.9)$ & $3(2.2)$ & $3(2.2)$ & $6(4.3)$ \\
\hline High & - & - & $2(1.5)$ & $3(2.2)$ & $3(2.2)$ & $2(1.5)$ \\
\hline \multicolumn{7}{|c|}{ Length-height/age } \\
\hline Suitable & $1(0.7)$ & $3(2.2)$ & $14(10.2)$ & $17(12.4)$ & $31(22.6)$ & $34(24.8)$ \\
\hline Low & - & - & $4(2.9)$ & $3(2.2)$ & $9(6.6)$ & $16(11.7)$ \\
\hline High & - & - & $2(1.5)$ & $2(1.5)$ & $1(0.7)$ & - \\
\hline \multicolumn{7}{|c|}{ Body mass index } \\
\hline Suitable & - & $3(2.2)$ & $14(10.2)$ & $17(12.4)$ & $35(25.5)$ & $28(20.4)$ \\
\hline Overweight & - & $1(0.7)$ & $3(2.2)$ & $5(3.7)$ & $7(5.1)$ & $17(12.4)$ \\
\hline Thinness & - & - & $3(2.2)$ & - & - & $4(3.0)$ \\
\hline
\end{tabular}

For the anthropometric measures weight/ age, $81.0 \%$ of the children were classified as suitable, most of them were boys (45.3\%). Among the children, $11.6 \%$ and $7.4 \%$ had changes to low and high weight, respectively; 12 were girls and 14 were boys, aged between 6 and 24 months. For the length-height/age measures, the suitable table was also found in most of the children $(72.9 \%)$, but $23.4 \%$ among boys and girls were classified as having low scores and 3.7\% with high scores. the latter with predominant ages between 6 and 12 months. Most children had an suitable body mass index $(70.7 \%)$, but $24.1 \%$ were overweight, most were male, with ages ranging from 13 to 24 months. As for thinness, $5.2 \%$ of cases were identified, and girls were exclusively affected.

In Table 2, the percentages of healthy children were higher for those living in the urban area. It is possible to identify deviations from overweight established for urban and rural areas - especially for the former. The other changes in the anthropometric measures were observed in children from both localities, but the percentage was high in the rural area, considering the total number of children examined, that is, of the 46 children evaluated, $26.1 \%$ showed some type of alteration.

Table 2 - Anthropometric measures of children, according to rural and urban location

\begin{tabular}{lcc}
\hline \multirow{2}{*}{ Variables } & $\begin{array}{c}\text { Urban area } \\
\mathbf{n = 9 1}\end{array}$ & $\begin{array}{c}\text { Rural area } \\
\mathbf{n = 4 6}\end{array}$ \\
\cline { 2 - 3 } & $\mathbf{n}(\mathbf{\%})$ & $\mathbf{n}(\%)$ \\
\hline Weight/age & & \\
Suitable & $72(79.1)$ & $39(84.8)$ \\
Low & $13(14.3)$ & $3(6.5)$ \\
High & $6(6.6)$ & $4(8.7)$ \\
Length-height/age & & \\
Suitable & $65(71.4)$ & $35(76.1)$ \\
Low & $22(24.2)$ & $10(21.7)$ \\
High & $4(4.4)$ & $1(2.2)$ \\
Body mass index & & \\
Suitable & $63(69.2)$ & $34(73.9)$ \\
Overweight & $22(24.2)$ & $11(23.9)$ \\
Thinness & $6(6.6)$ & $1(2.2)$ \\
\hline
\end{tabular}

Considering the relationship of the variables, table 3 shows the statistical association between the anthropometric measures and the age and area variables analyzed, considering $\mathrm{p}<0.05$. Among the measures, most were suitable and belonged to the age group of 13 to 24 months, but the incidence of this population was in the rural area. 
Table 3 - Association between the variables regarding the anthropometric measures, the age group, and the location

\begin{tabular}{|c|c|c|c|c|c|c|c|c|c|}
\hline \multirow{2}{*}{ Variables } & \multicolumn{3}{|c|}{ Weight/age (\%) } & \multicolumn{3}{|c|}{ Length-height/age (\%) } & \multicolumn{3}{|c|}{ Body mass index (\%) } \\
\hline & Suitable & Low & High & Suitable & Low & High & Suitable & Overweight & Thinness \\
\hline Age group (months) & 81 & 11.6 & 7.4 & 72.9 & 23.4 & 3.7 & 70.7 & 24.1 & 5.2 \\
\hline$<6$ & 2.9 & 0,0 & 0,0 & 2.9 & 0.0 & 0.0 & 2.2 & 0.7 & 0.0 \\
\hline $6-12$ & 21.4 & 5.1 & 3.7 & 22.6 & 5.1 & 3.0 & 22.6 & 5.9 & 2.2 \\
\hline $13-24$ & 56.2 & 6.5 & 3.7 & 47.4 & 18.3 & 0.7 & 45.9 & 17.5 & 3.0 \\
\hline p-value & & 0.040 & & & 0.000 & & & $0.000^{*}$ & \\
\hline Zone & 163.9 & 20.8 & 15.3 & 147.5 & 45.9 & 6.6 & 143.1 & 48.1 & 8.8 \\
\hline Urban & 79.1 & 14.3 & 6.6 & 71.4 & 24.2 & 4.4 & 69.2 & 24.2 & 6.6 \\
\hline Rural & 84.8 & 6.5 & 8.7 & 76.1 & 21.7 & 2.2 & 73.9 & 23.9 & 2.2 \\
\hline$p$-value & & 0.000 & & & $0.020^{*}$ & & & 0.010 & \\
\hline
\end{tabular}

\section{Discussion}

The adopted cross-sectional design was considered as a limitation of the study, which does not provide a basis for the verification of causality, hindering to see changes in the growth of children attending nursery.

Regarding the characteristics of the children, most of them presented age above six months, concentrating between seven and 24 months, with suitable birth weight and gestational age. However, a small percentage was born prematurely and below ideal weight. Both variables constitute important health problems and are associated with a deficit in weight, which can persist from childhood to adulthood, favoring the occurrence of morbidities. Malnutrition stands out among the most frequent morbidities ${ }^{(10)}$.

Childcare is considered a fundamental strategy for the regular follow-up of the child after birth and has been practiced in the researched region. However, it can be seen that a percentage of children do not perform regular consultations, which can compromise one of their most important purposes, which refers to the monitoring of child growth and development, and to the identification of problems related to nutritional disorders, such as identified in this sample, as well as the promotion and recovery of health, resulting from this and other diseases.
Most of the children had complete vaccination schedule, but some were late, exposing the child to diseases, including viral and bacterial, which can cause insufficient intake of nutrients, impacting on nutritional absorption and infant growth.

Daycare centers are key places for childcare for many families, especially low-income families, as they allow parents to enter the labor market, increase incomes, and consequently improve family living conditions. Children who lived in the urban area and who attended the day care center were predominantly in the study, being usually enrolled before 12 months. Full-time stay may be a major concern with respect to stimuli and promotions about healthy routines offered in these educational settings since children, in general, tend to reproduce habits learned in places where they spend most of their time in schools and kindergartens ${ }^{(11)}$.

Also, it is plausible to understand that, although most of the children presented the percentile within the expected weight and length/height for age, the boys had a higher percentage of nutritional alteration, mainly between six and 24 months, corroborating findings of Brazilian study, in which $10.1 \%$ and $7.0 \%$ percentages were identified for overweight and obesity among children of the same sex and with a mi- 
nimum income per capita $(10.9 \% \text { and } 6.2 \%)^{(12)}$.

Regarding the spatial distribution, a larger number of changes were identified in daycare children in the urban zone, a fact possibly justified because the sample is larger in that territory. However, rural children revealed significant percentages of changes when considering the total population analyzed. This shows the need for greater attention to be paid to monitoring the growth of children in rural areas.

The risk of overweight and/or proven obesity among children has been gaining prominence in the global epidemiological scenario, including in developing countries, due to its increasing prevalence and, mainly, serious health risks in a global way, such as emotional and such as anxiety and depression ${ }^{(13)}$. One of the reasons for the excess weight revealed in this sample is possibly associated to changes in habits regarding inadequate feeding, considering the increase in the consumption of industrialized foods, with low nutritive content and high caloric content, corroborating research carried out in Pelotas, Brazil ${ }^{(14)}$.

Considering the clinical risks of nutritional disorders, such as hyperinsulinemia, cardiovascular risk, insulin resistance, rheumatic, orthopedic and psychosocial diseases in overweight and obese children, it is fundamental that child health surveillance practices are performed routinely in day care centers, since these environments should ensure favorable conditions for the growth and development of the child, including healthy eating ${ }^{(15)}$. It is suggested that health education practices be carried out by professionals in the area for caregivers, daycare managers, parents, and caregivers, especially for children identified as obese, overweight and risk for overweight. Among the guidelines, it is important to include subjects related to the introduction of healthier behaviors/habits, reducing negative consequences, such as future diseases, to which children with changes in anthropometric indices are exposed.

\section{Conclusion}

From the evaluation of the nutritional status of children attending municipal daycare centers, it was possible to understand that, although most of the children studied were age-suitable, changes in the nutritional profile of some of them were identified, such as overweight, especially among those males, aged between six and 24 months and living in the urban area. This reinforces the importance of anthropometric evaluation in the identification and intervention of nutritional changes in children.

\section{Collaborations}

Torquato IMB and Dias HP contributed in designing the project, collecting, analyzing and interpreting the data. Collet N, Souza MA and Dantas MSA contributed to the writing of the article and critical review relevant intellectual content. Reichert APS contributed to the critical review of the content and approval of the final version to be published.

\section{References}

1. Fernandes ECB, Castro TG, Sartorelli DS. Associated factors of malnutrition among African children under five years old, Bom Jesus, Angola. Rev Nutr PUCCAMP. 2017; 30(1):33-44. doi: http://dx.doi. org/10.1590/1678-98652017000100004

2. Carvalho CA, Fônseca PCA, Piore SE, Franceschini SCC, Novaes JF. Food consumption and nutritional adequacy in Brazilian children: a systematic review. Rev Paul Pediatr. 2015; 33(2):211-21. doi: https://doi.org/10.1016/j.rpped.2015.03.002

3. Pedraza DF, Bezerra TA. Nutritional status of children under five years living in area of social vulnerability of Campina Grande, Paraíba State. Acta Sci Health Sci. 2016; 38(1):81-8. doi: http:// dx.doi.org/10.4025/actascihealthsci.v38i1.29155 
4. Goisis A, Sacker N, Kelly Y. Why are poorer children at higher risk of obesity and overweight? A UK cohort study. Eur J Public Health. 2016; 26(1):713. doi: https://doi.org/10.1093/eurpub/ckv219

5. Pedraza DF, Santos IS. Assessment of growth monitoring in child care visits at the Family Health Strategy in two municipalities of Paraíba State, Brazil. Epidemiol Serv Saúde. 2017; 26(4):847-55. doi: 10.5123/S1679-49742017000400015

6. Santos NCCB, Pinto MB, Henriques AHB, Cavalcanti JRD, Brito CC, Reichert APS. Vigilância à saúde das crianças em creche municipal: enfoque no perfil nutricional. Rev Rene [Internet]. 2013 [citado 2018 abr. 13]; 14(4):704-12. Disponível em: http://www.revistarene.ufc.br/revista/index. php/revista/article/viewFile/1110/pdf

7. Ramires EKNM, Menezes RCE, Oliveira JS, Oliveira MAA, Temoteo TL, Silva GL, et al. Nutritional status of children and adolescents from a town in the semiarid Northeastern Brazi. Rev Paul Pediatr. 2014; 32(3):200-7. doi: http://dx.doi. org/10.1590/0103-0582201432309

8. Said-Mohamed R, Micklesfield LK, Pettifor JM, Shane A. Has the prevalence of stunting in South African children changed in 40 years? A systematic review. BMC Public Health. 2015; 15(534):2-10. doi: http://doi.org/10.1186/s12889-015-1844-9

9. Ministério da Saúde (BR). Caderneta de saúde da criança. Brasília: Ministério da Saúde; 2013.

10. Pessoa TAO, Martins CBG, Lima FCA, Gaíva MAM. O crescimento e desenvolvimento frente à prematuridade e baixo peso ao nascer. Av Enferm. 2015; 33(3):401-11. doi: http://dx.doi. org/10.15446/av.enferm.v33n3.44425
11. Bento IC, Esteves JMM, França TE. Alimentação saudável e dificuldades para torná-la uma realidade: percepções de pais/responsáveis por pré-escolares de uma creche em Belo Horizonte/ MG, Brasil. Ciênc Saúde Coletiva. 2015; 20(8):2389400. doi: http://dx.doi.org/10.1590/141381232015208.16052014

12. Pereira IFS, Andrade LMB, Spyrides MHC, Lyra CO. Nutritional status of children under 5 years of age in Brazil: evidence of nutritional epidemiological polarization. Ciênc Saúde Coletiva. 2017; 22(10):3341-52. doi: http://dx.doi. org/10.1590/1413-812320172210.25242016

13. Pedraza DF, Silva FA, Melo NLS, Araújo EMN, Sousa CPC. Estado nutricional e hábitos alimentares de escolares de Campina Grande, Paraíba, Brasil. Ciênc Saúde Coletiva. 2017; 22(2):469-77. doi: http://dx.doi.org/10.1590/141381232017222.2 6252015

14. Leal KK, Schneider BC, França GVA, Gigante DP, Santos I. Assunção MCF. Diet quality of preschool children aged 2 to 5 years living in the urban area of Pelotas, Brazil. Rev Paul Pediatr. 2015; 33(3):310-7. doi: http://dx.doi.org/10.1016/j. rpped.2015.05.002

15. Ferreira SD, Carballo FP, Sousa FF, Silva DMR. Prevalência e fatores associados ao sobrepeso/ obesidade e à hipertensão arterial sistêmica em crianças da rede privada de ensino de Divinópolis/ MG. Cad Saúde Coletiva 2015; 23(3):28997. doi: http://dx.doi.org/10.1590/1414462X201400060082 